Dhaka Univ. J. Biol. Sci. 21(2): 131-140, 2012 (July)

\title{
LIMNOLOGY OF A CONSERVED MAN-MADE LAKE IN BANGLADESH. I. PHYSICAL AND CHEMICAL FACTORS
}

\author{
Roksana Begum, Moniruzzaman KhondKer ${ }^{1}$ And Md. Shafiqul Islam \\ Department of Botany, University of Dhaka, Dhaka-1000, Bangladesh \\ Key words: Man-made lake, Limnology, Physical, Chemical
}

\begin{abstract}
Limnological investigation on a conserved man-made lake located in the Safipur Ansar and VDP Academy, Gazipur district has been carried out between July, 2008 and May, 2009. Thirteen limnological parameters were measured mostly at fortnight intervals and their annual and seasonal fluctuations were observed. The lake water was slightly alkaline in nature having a monthly mean $\mathrm{pH}$ range $7.26-7.91$. The water temperature varied from $18-32^{\circ} \mathrm{C}$. Soluble reactive phosphorus, soluble reactive silicate and nitrate nitrogen ranged from 9.22 - $154.57 \mu \mathrm{g} / \mathrm{l}, 2.52$ - 17.06 and 0.17 - $187 \mathrm{mg} / \mathrm{l}$, respectively.
\end{abstract}

\section{Introduction}

Conservation of freshwater resources has now become an issue of global concern because water is one of the vital resources to the modern society. Bangladesh, because of its geographical location holds adequate reserves of freshwater but due to excessive population pressure very few of her water bodies retain good water quality and aquatic biodiversity. A number of limnological investigations have been carried out in some man-made lakes situated in and around Dhaka metropolis ${ }^{(1-4)}$ to evaluate their water quality and biodiversity. Urban based man-made lakes are usually created for meeting the demands of emergency water supply and to fulfil aesthetic and environmental needs. Most of these created lake waters are abused so strongly by dumping solid wastes, discharging waste water and sewages that hardly any emergency water requirement need can be met with this water. On the other hand, those water bodies could not be enjoyed as a place for human recreation. A conservation strategy is usually suggested for the reclamation of those lakes.

Man-made lakes are vulnerable towards the disposal of organic matter and sewage inflows which makes the lake water very rich in organic matter and to support a luxuriant algal bloom almost all over the year. This nuisance actually hampers the main goal of creating such a water body. Beyond this, a very few man-made lakes are protected against this kind of contamination through strong administrative measures. Limnology in respect to the water quality, phytoplankton quality and quantity and terminal production must be different in these two categories of man-made lakes.

${ }^{1}$ Author for correspondence: <mkhondker@yahoo.com> 
The present lake, in concern, is situated in the Safipur Ansar and VDP Academy in Gazipur district. The lake has been created to increase the beauty of the locality and also for meeting the needs of emergency water supply. The lake is conserved against any external input of pollutants and to keep its water free of hazardous elements. Routine aquaculture is also being practiced in the lake water. The aim of the present research is to study the diversity of phytoplankton and limnology of such a conserved lake.

\section{Materials and Methods}

The studied lake is situated $30 \mathrm{~km}$ north east of Dhaka Metropolis within the campus of Bangladesh Ansar and VDP Academy, Gazipur district. The geolocation being $24^{\circ} 00^{\prime}-$ $24^{\circ} 15^{\prime} \mathrm{N}$ and $90^{\circ} 15^{\prime}-90^{\circ} 30^{\prime} \mathrm{E}$. The lake was excavated in 1985 on agricultural land. Its area is 1.25 ha and the depth ranged from $2.0-2.5 \mathrm{~m}$. It is perennial and rain fed. A permanent station was set up for carrying out routine sampling. The sampling was done mostly at 15 days interval between July, 2008 and May, 2009 and altogether a total of 23 samples were collected. On each sampling occasion the lake was reached around 09:00 a.m. and the sampling began from the fixed station. Air and water temperature was measured with the help of a graduated mercury centigrade thermometer. From $10 \mathrm{~cm}$ depth 5 liter water sample was collected by a black canister. Duplicate BOD bottles (125 $\mathrm{ml}$ cap.) was filled by the same water and fixed in situ by adding each of $1 \mathrm{ml}$ of manganous sulfate and Winkler's reagent. $\mathrm{pH}$, TDS and conductivity of water was measured in situ (Griffin pH meter, Model-50, UK; Hanna HI 9034, Hanna, HI 9033, Singapore). All the collected and fixed samples were transported to the Hydrobiology and Limnology Laboratory, Department of Botany, University of Dhaka within the next one and half an hour.

Two hundred fifty $\mathrm{ml}$ well mixed sample water was filtered through a Sartorius filtration device using a vacuum pump and Whatman GF/C filter paper (circle dia. 47 $\mathrm{mm}$ ). After filtration the filtrate was used for nutrient analysis. Sub-samples of filtrate were used to determine SRP, SRS and $\mathrm{NO}_{3}-\mathrm{N}^{(5-7)}$. Alkalinity was determined by using unfiltered sample ${ }^{(8)}$ and DO by using the samples fixed in situ(6). Monthly data were pulled to mean values and plotted (Fig. 1A-F).

\section{Results and Discussion}

All physicochemical data measured in the present investigation have been presented in Table 1 and Fig. 1 . Air and water temperature ranged from $17.5-33.5$ and $18-32^{\circ} \mathrm{C}$, respectively. $\mathrm{pH}$ of water ranged from $7.26-7.91$, conductivity from $106.75-372.00$ $\mu \mathrm{S} / \mathrm{cm}$ and TDS from $55.00-114.75 \mathrm{mg} / \mathrm{l}$. Whereas, the alkalinity ranged from $1.25-4.10$ meq/l and DO from 4.98 - $9.66 \mathrm{mg} / \mathrm{l}$ (Table 1). The SRP and $\mathrm{NO}_{3}-\mathrm{N}$ concentrations in the beginning of the study i.e, July, 2008 were very high, $154.57 \mu \mathrm{g} / \mathrm{l}$ and $187.54 \mathrm{mg} / \mathrm{l}$,

respectively (Table 1). Without this exceptional concentration, SRP showed a fluctuating 
trend from 5.12 - $31.71 \mu \mathrm{g} / \mathrm{l} . \mathrm{NO}_{3}-\mathrm{N}$ concentrations in the lake water were always in the lowermost ranged from $0.02-0.58 \mathrm{mg} / \mathrm{l}$. Silicate concentration ranged from $2.52-17.06$ $\mathrm{mg} / \mathrm{l}$.

The lake is almost free from any external pollution sources except via precipitation and seepage. The lake was not previously investigated limnologically. So, the present limnological investigation highlights some of the water quality parameters in the lake for the first time.

Table. 1. Physical and chemical variables of the water sample.

\begin{tabular}{|c|c|c|c|c|c|c|c|c|c|c|c|}
\hline Month & & $\begin{array}{c}\text { Air } \\
\text { temp. } \\
\left({ }^{\circ} \mathrm{C}\right)\end{array}$ & $\begin{array}{c}\text { Water } \\
\text { temp. } \\
\left({ }^{\circ} \mathrm{C}\right)\end{array}$ & $\mathrm{pH}$ & $\begin{array}{l}\text { Cond. } \\
(\mu S / \mathrm{cm})\end{array}$ & $\begin{array}{c}\text { TDS } \\
(\mathrm{mg} / \mathrm{l})\end{array}$ & $\begin{array}{l}\text { Alka- } \\
\text { linity } \\
\text { (meq/l) }\end{array}$ & $\begin{array}{c}\mathrm{DO} \\
(\mathrm{mg} / \mathrm{l})\end{array}$ & $\begin{array}{l}\text { SRP } \\
(\mu \mathrm{g} / 1)\end{array}$ & $\begin{array}{l}\text { SRS } \\
(\mathrm{mg} / \mathrm{l})\end{array}$ & $\begin{array}{l}\mathrm{NO}_{3}-\mathrm{N} \\
(\mathrm{mg} / \mathrm{l})\end{array}$ \\
\hline & A & 29.00 & 28.00 & nd & 372.00 & 62.00 & 1.50 & 8.13 & 31.71 & 16.88 & *187.54 \\
\hline July & B & 29.00 & 28.50 & nd & 221.00 & 73.00 & 1.35 & 7.22 & 18.71 & 14.16 & 0.27 \\
\hline 2008 & $\mathrm{C}$ & 28.50 & 27.00 & nd & 150.00 & 70.50 & 1.30 & 4.98 & ${ }^{*} 154.57$ & 13.08 & 0.00 \\
\hline Aug. & A & 28.00 & 26.50 & 7.58 & 153.00 & 71.50 & 3.00 & 9.66 & 9.22 & 12.54 & 0.39 \\
\hline 2008 & B & 24.00 & 23.00 & 7.48 & 162.25 & 76.25 & 1.45 & 5.69 & 7.41 & 14.28 & 0.02 \\
\hline Sept. & A & 24.00 & 23.00 & 7.46 & 136.33 & 64.25 & 1.60 & 7.42 & 9.48 & 12.64 & 0.07 \\
\hline 2008 & B & 22.00 & 21.00 & 7.26 & 128.63 & 60.75 & 1.75 & 5.59 & 19.87 & 15.40 & 0.04 \\
\hline Oct. & A & 22.50 & 21.00 & 7.51 & 128.00 & 61.25 & 1.60 & 6.61 & 0.00 & 13.24 & 0.10 \\
\hline 2008 & B & 21.00 & 20.00 & 7.37 & 106.75 & 55.00 & 1.60 & 8.84 & 17.92 & 13.20 & 0.10 \\
\hline Nov. & A & 22.50 & 20.00 & 7.72 & 115.25 & 60.50 & 1.80 & 8.03 & 12.98 & 10.61 & 0.12 \\
\hline 2008 & B & 18.00 & 19.50 & 7.48 & 123.00 & 66.25 & 1.50 & 7.72 & 13.34 & 10.46 & 0.08 \\
\hline Dec. & A & 18.00 & 19.00 & 7.89 & 116.5 & 61.50 & 1.40 & 7.22 & 5.89 & 9.60 & 0.14 \\
\hline 2008 & B & 17.00 & 18.50 & 7.71 & 117.50 & 61.25 & 1.25 & 8.13 & 6.10 & 10.69 & 0.00 \\
\hline Jan. & A & 17.00 & 18.00 & 7.91 & 115.00 & 62.00 & 1.70 & 8.13 & 7.11 & 11.04 & 0.10 \\
\hline 2009 & B & 20.00 & 20.00 & 7.79 & 128.50 & 69.50 & 1.45 & 7.42 & 6.87 & 15.51 & 0.09 \\
\hline Feb. & A & 20.50 & 22.00 & 7.26 & 141.00 & 86.00 & 2.30 & 7.83 & 13.89 & 17.06 & 0.15 \\
\hline 2009 & B & 25.50 & 24.50 & 7.34 & 153.50 & 95.75 & 1.80 & 7.01 & 6.94 & 15.25 & 0.17 \\
\hline Mar. & A & 28.00 & 26.50 & 7.31 & 166.75 & 95.00 & 1.90 & 7.52 & 5.12 & 12.02 & 0.42 \\
\hline 2009 & B & 30.00 & 28.00 & 7.60 & 189.25 & 104.75 & 2.00 & 5.38 & 7.70 & 8.31 & 0.33 \\
\hline Apr. & A & 30.50 & 29.00 & 7.86 & 214.75 & 114.75 & 2.10 & 6.61 & 0.00 & 6.01 & 0.13 \\
\hline 2009 & B & 30.50 & 29.00 & 7.61 & 199.5 & 109.25 & 2.20 & 5.69 & 15.61 & 2.52 & 0.23 \\
\hline May & A & 32.00 & 30.00 & 7.90 & 210.50 & 108.25 & 4.10 & 7.22 & 5.74 & 5.61 & 0.06 \\
\hline 2009 & $\mathrm{~B}$ & 33.50 & 32.00 & 7.80 & 192.25 & 97.00 & 3.80 & 5.99 & 9.87 & 6.54 & 0.07 \\
\hline \multicolumn{2}{|c|}{ Mean value } & 24.83 & 24.09 & 7.59 & 162.65 & 77.66 & 1.93 & 7.13 & 10.52 & 11.59 & 0.14 \\
\hline
\end{tabular}

*Values not included in the annual mean calculation. $(\mathrm{A}=1$ st fortnight, $\mathrm{B} / \mathrm{C}=2 \mathrm{nd}$ fortnight, $\mathrm{n}=23)$, nd $=$ not determined.

This lake is shallow in nature $\left(Z_{\max }=2.0-2.5 \mathrm{~m}\right)$ and in Bangladesh thermal stratification is not possible with a water depth lesser than $10 \mathrm{~m}^{(9)}$. So, it indicates that the principle of wind induced mixing in shallow water is strictly working here. Regarding surface water temperature it followed the general seasonal pattern i.e. lower water 
temperature during the winter month (December $18.75^{\circ} \mathrm{C}$ ) which is usual for other manmade lakes so far studied in Bangladesh i.e., $\sim 20^{\circ} \mathrm{C}^{(10-12)}$. Annual mean water temperature is also closer to other man-made lakes of Bangladesh (Table 4).

Table 2. Monthly mean values of different limnological parameters from the lake.**

\begin{tabular}{lccccccccccc}
\hline Parameters & July & Aug. & Sept. & Oct. & Nov. & Dec. & Jan. & Feb. & Mar. & Apr. & May \\
\hline Air temp. $\left({ }^{\circ} \mathrm{C}\right)$ & 28.83 & 26 & 23 & 21.75 & 20.25 & 17.50 & 18.5 & 23 & 29 & 30.5 & 32.75 \\
Water temp. $\left({ }^{\circ} \mathrm{C}\right)$ & 22.83 & 24.75 & 22 & 20.5 & 19.75 & 18.75 & 19.00 & 23.25 & 27.25 & 29.00 & 31.00 \\
pH & nd & 7.53 & 7.36 & 7.44 & 7.60 & 7.80 & 7.85 & 7.30 & 7.46 & 7.74 & 7.85 \\
Cond $(\mu \mathrm{S} / \mathrm{cm})$ & 247.67 & 157.63 & 132.48 & 117.38 & 119.13 & 116.88 & 121.75 & 147.25 & 178.00 & 207.13 & 210.38 \\
TDS $(\mathrm{mg} / \mathrm{l})$ & 68.5 & 73.88 & 62.5 & 58.13 & 63.38 & 61.38 & 65.75 & 90.86 & 99.88 & 112.00 & 102.63 \\
Alkal. $(\mathrm{meq} / \mathrm{l})$ & 1.38 & 2.22 & 1.68 & 1.60 & 1.65 & 1.33 & 1.58 & 2.05 & 1.95 & 2.15 & 3.95 \\
DO $(\mathrm{mg} / \mathrm{l})$ & 6.78 & 7.68 & 6.51 & 7.73 & 7.88 & 7.68 & 7.78 & 7.42 & 6.45 & 6.15 & 6.61 \\
SRP $(\mu \mathrm{g} / \mathrm{l})$ & $* 25.21$ & 8.32 & 14.67 & 8.96 & 13.16 & 5.99 & 6.99 & 10.42 & 6.41 & 7.81 & 7.81 \\
SRS $(\mathrm{mg} / \mathrm{l})$ & 14.70 & 13.41 & 14.02 & 13.22 & 10.54 & 10.15 & 13.28 & 16.16 & 10.27 & 4.27 & 6.08 \\
\hline
\end{tabular}

**( $\mathrm{n}=2$, except July, 2008, where $\mathrm{n}=3)$, nd = Not determined.

Table 3. Average value of different limnological parameters in four distinct seasons of Bangladesh.

\begin{tabular}{|c|c|c|c|c|c|}
\hline Parameters & Unit & $\begin{array}{c}\text { Winter } \\
\text { (Late } \\
\text { November- } \\
\text { February) }\end{array}$ & $\begin{array}{c}\text { Summer } \\
\text { (March - May) }\end{array}$ & $\begin{array}{c}\text { Monsoon } \\
\text { (June - Early } \\
\text { October) }\end{array}$ & $\begin{array}{c}\text { Autumn } \\
\text { (Late October - } \\
\text { early } \\
\text { November) }\end{array}$ \\
\hline Air temp. & $\left({ }^{\circ} \mathrm{C}\right)$ & $19.42 \pm 3.00$ & $30.08 \pm 1.86$ & $25.88 \pm 3.03$ & $21.75 \pm 1.06$ \\
\hline Water temp. & $\left({ }^{\circ} \mathrm{C}\right)$ & $20.22 \pm 2.28$ & $29.08 \pm 1.86$ & $24.75 \pm 3.09$ & $20.0 \pm 0$ \\
\hline $\mathrm{pH}$ & & $7.62 \pm 0.26$ & $7.86 \pm 0.22$ & $7.46 \pm 0.12$ & $7.54 \pm 0.25$ \\
\hline Conductivity & $\mu \mathrm{S} / \mathrm{cm}$ & $127.82 \pm 14.5$ & $195.5 \pm 17.2$ & $181.40 \pm 81.6$ & $111 \pm 6.01$ \\
\hline TDS & $\mathrm{mg} / \mathrm{l}$ & $71.75 \pm 13.69$ & $104.83 \pm 7.58$ & $67.44 \pm 6.06$ & $57.75 \pm 3.89$ \\
\hline Alkalinity & meq/1 & $1.63 \pm 0.35$ & $2.68 \pm 0.99$ & $1.69 \pm 0.55$ & $1.7 \pm 0.14$ \\
\hline DO & $\mathrm{mg} / \mathrm{l}$ & $7.63 \pm 0.44$ & $6.49 \pm 0.86$ & $6.91 \pm 1.53$ & $8.44 \pm 0.57$ \\
\hline SRP & $\mu \mathrm{g} / 1$ & $8.59 \pm 3.46$ & $7.34 \pm 5.22$ & $* 13.78 \pm 1.52$ & $15.45 \pm 3.49$ \\
\hline SRS & $\mathrm{mg} / \mathrm{l}$ & $12.80 \pm 3.02$ & $6.84 \pm 3.16$ & $14.03 \pm 1.49$ & $11.91 \pm 1.83$ \\
\hline $\mathrm{NO}_{3}-\mathrm{N}$ & $\mathrm{mg} / \mathrm{l}$ & $0.11 \pm 0.06$ & $0.21 \pm 0.15$ & ${ }^{*} 0.14 \pm 0.06$ & $0.11 \pm 0.02$ \\
\hline
\end{tabular}

The range of variation in $\mathrm{pH}$ was from 7.25 - 7.90. Similar narrow fluctuation has also been recorded by Khondker and Parveen(2) and Kabir(9). The average $\mathrm{pH}$ value is approximately near about to that recorded for Dhanmondi lake, Banani lake and Gulshan lake ${ }^{(11,13,14)}$. Mean annual $\mathrm{pH}$ of the present lake (7.59) is similar to that recorded for Dhanmondi lake (7.58). Slightly lower value was recorded for Banani and Gulshan lake (Table 4). Annual mean pH $7.59 \pm 0.22$ qualifies the water as slightly alkaline in nature. This is quite normal for most surface waters of Bangladesh with a few exceptions (Table $4)$. 
The annual average conductivity of this lake showed a minimal value (162.65 $\mu \mathrm{S} / \mathrm{cm})$ than Dhanmondi lake $(565.42 \mu \mathrm{S} / \mathrm{cm})$, Gulshan lake $(196.1 \mu \mathrm{S} / \mathrm{cm})$ and Banani lake $(337.23 \mu \mathrm{S} / \mathrm{cm})(340.10 \mu \mathrm{S} / \mathrm{cm}) .{ }^{(2,11,14)}$ The conductivity value of this lake is closer to Crescent lake ( $158.57 \mu \mathrm{S} / \mathrm{cm}$ ) and Gulshan lake $(196.1 \mu \mathrm{S} / \mathrm{cm})$ (Table 4). In the present investigation the highest conductivity value was obtained in summer (Table 3), which indicates that the highest free ionic load occurs during this period. This may be a result of crucial breakdown of organic and inorganic matters in the water body and this was followed by high phytoplankton densities in dry months.

Table 4. A comparative limnology of different man-made lakes (data indicate average value).

\begin{tabular}{|c|c|c|c|c|c|c|}
\hline Parameters & Unit & $\begin{array}{c}\text { Present } \\
\text { investigation } \\
(\mathrm{n}=23)\end{array}$ & $\begin{array}{c}\text { DL } \\
\text { (Khondker and } \\
\text { Rahim 1990) } \\
(\mathrm{n}=22)\end{array}$ & $\begin{array}{c}\text { CL } \\
\text { (Mukhtar } \\
1993) \\
(\mathrm{n}=22)\end{array}$ & $\begin{array}{c}\text { BL } \\
\text { (Rahman } \\
1993) \\
(\mathrm{n}=22)\end{array}$ & $\begin{array}{c}\text { GL } \\
\text { (Chowdhury } \\
1993) \\
(\mathrm{n}=22)\end{array}$ \\
\hline Water temp. & ${ }^{\circ} \mathrm{C}$ & 24.09 & 28.48 & 27.19 & 25.87 & 26.32 \\
\hline $\mathrm{pH}$ & & 7.59 & 7.58 & 9.14 & 7.30 & 7.40 \\
\hline Conductivity & $\mu \mathrm{S} / \mathrm{cm}$ & 162.65 & 565.42 & 158.57 & 337.23 & 196.1 \\
\hline TDS & $\mathrm{mg} / \mathrm{l}$ & 77.66 & - & - & - & - \\
\hline Alkalinity & meq/1 & 1.93 & 3.62 & 1.09 & 2.25 & 1.28 \\
\hline DO & $\mathrm{mg} / \mathrm{l}$ & 7.13 & 11.57 & 14.16 & 3.91 & 5.04 \\
\hline SRP & $\mu \mathrm{g} / \mathrm{l}$ & $10.52^{*}$ & 780 & 370 & 390 & 47.34 \\
\hline SRS & $\mathrm{mg} / \mathrm{l}$ & 11.59 & 30.55 & 42.61 & 33.68 & 24.16 \\
\hline $\mathrm{NO}_{3}-\mathrm{N}$ & $\mathrm{mg} / \mathrm{l}$ & $0.138^{*}$ & 0.21 & 0.73 & 0.008 & 0.23 \\
\hline
\end{tabular}

$\mathrm{SL}=$ Safipur Lake, Safipur Anser VDP Academy, Safipur, Gajipur, Dhaka; DL = Dhanmondi Lake, Dhaka (Hyper-eutrophic); $\mathrm{CL}=$ Crescent Lake, Sher-E-Bangla Nagar, Dhaka (Mesotrophic); BL= Banani Lake, Dhaka; $\mathrm{GL}=$ Gulshan Lake, Dhaka. ${ }^{*}$ Mean has been calculated excluding the value of one very high record.

TDS load in the pelagic water of this lake varied from 55.00 - $114.75 \mathrm{mg} / \mathrm{l}$ (Table 1). The data could not be compared with other man-made lakes because of its absence in them. However, a study from some pond ecosystems of the southern part of Bangladesh indicates a range of $5.13-2165 \mathrm{mg} / \mathrm{l}^{(15)}$ for this parameter. Compared to this result the TDS load of the present lake shows a lower scale.

Table 4 depicts the comparative analyses of alkalinity values from different other man-made lakes of Bangladesh. In this comparison the annual mean alkalinity fall in a third highest category compared to Dhanmondi and Banani lake (Table 4). Alkalinity values of two other lakes, namely Crescent and Gulshan lake are lower than the present lake (Table 4). 

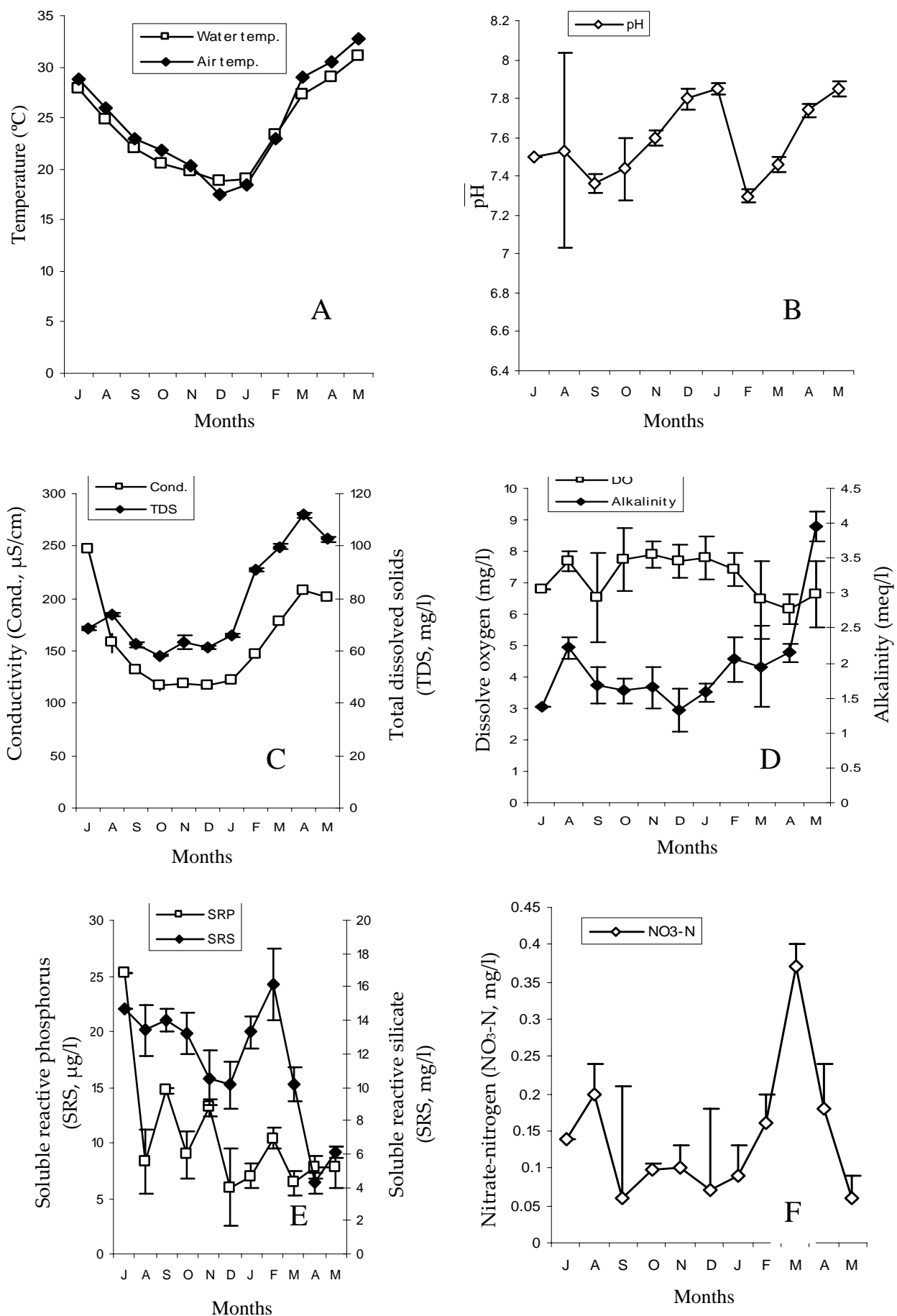

Fig. 1A-F: Monthly fluctuation of different physicochemical factors of the lake. A. Water and air temperature. B. pH. C. Conductivity and total dissolved solids. D. Dissolved oxygen and alkalinity. E. Soluble reactive phosphorus and soluble reactive silicate. F. Nitrate-nitrogen. 
There is not very high fluctuations in the concentration of dissolved oxygen (DO) content in the lake, which might be due to temperature, rainfall, absence of macrophytes and the plankton population of the lake. Lower oxygen content $(4.98 \mathrm{mg} / \mathrm{l})$ was obtained in monsoon and this value is near about two-fold less than the highest value. The annual average DO of the lake is $7.13 \mathrm{mg} / \mathrm{l}$, which is half compared to Crescent lake and less than Dhanmondi lake(2) but greater than Banani and Gulshan lake (Table 4). Extremely low value as indicated in the Gulshan and Banani lake (3.91 - $5.40 \mathrm{mg} / \mathrm{l})$ and high value as indicated in Dhanmondi and Crescent lake (11.57 - $14.16 \mathrm{mg} / \mathrm{l})$ are all indicators of eutrophicated water. The mean DO $(7.13 \mathrm{mg} / \mathrm{l})$ as recorded in the present investigation indicates a good water quality.

The highest concentration of soluble reactive phosphorus (SRP) was measured in monsoon and lowest in summer (Table 3). The average SRP concentration in the lake was $10.52 \mu \mathrm{g} / \mathrm{l}$. SRP concentration reported for some eutrophic lakes of other regions, namely Suraha lake ${ }^{(16)}$, reservoir and lakes of south Holland(17) are 60, 90 and $500 \mu \mathrm{g} / \mathrm{l}$, respectively. Compared to these water bodies the SRP concentration is much lower. Annual mean phosphorus concentration of some man-made lakes of Bangladesh, namely Dhanmondi, Crescent and Banani lakes show values of 780, 370 and $390 \mu \mathrm{g} / \mathrm{l}$. These are also very high values compared to Safipur lake $(10.52 \mu \mathrm{g} / \mathrm{l})$. Since phosphorus is considered to be a key nutrient to trigger phytoplankton biomass so, in terms of mean SRP concentration the present lake shows a better water quality. A very high SRP was recorded in July which might have resulted because of lake fertilization for aquaculture.

The silicate content of Safipur lake is the lowest compared to all other studies carried out on man-made lakes in Bangladesh (Table 4). Actually silica metabolism is associated with diatom population. According to Welch ${ }^{(18)}$ much of the dissolved silicate becomes utilized by diatoms resulting in the lower concentration of silicate in water. The present lake is very poor in diatom population, Bacillariophyceae was represented by $5.75 \%$ of the total population.

Very low seasonal fluctuation of nitrate $\left(\mathrm{NO}_{3}-\mathrm{N}\right)$ was observed in the selected lake of Safipur except the value of 3 July, 2008. Table 4 shows a comparative analysis of this data with some other man-made lakes. The mean nitrate concentration for most of the periods for Safipur lake was much lower than Dhanmondi, Crescent and Gulshan lakes (Table 4). Banani lake has shown a very low mean nitrate concentration $(0.008 \mathrm{mg} / \mathrm{l})$. The extremely high value for Safipur lake which was recorded in July, 2008 might be due to fertilization of the lake for aquaculture. A moderate effect of temperature on the nitrate $\left(\mathrm{NO}_{3}-\mathrm{N}\right)$ content was found in the mean seasonal value (Table 4).

The present limnological study on Safipur lake shows a good water quality of the lake as it has been indicated by annual mean values of some key limnological parameters such as water temperature $\left(24.9^{\circ} \mathrm{C}\right), \mathrm{pH}(7.59)$, alkalinity $(1.93 \mathrm{meq} / \mathrm{l}), \mathrm{DO}$ 
Table 5. Matrix of product moment correlation coefficient (r) among different physico-chemical and biological variables recorded from the sampling station.

\begin{tabular}{|c|c|c|c|c|c|c|c|c|c|c|}
\hline & & $\begin{array}{l}\text { Water } \\
\text { temp. }\end{array}$ & $\mathrm{pH}$ & $\begin{array}{c}\text { Conduc- } \\
\text { tivity }\end{array}$ & TDS & $\begin{array}{l}\text { Alka- } \\
\text { linity }\end{array}$ & DO & SRP & SRS & $\mathrm{NO}_{3}-\mathrm{N}$ \\
\hline \multirow{3}{*}{$\begin{array}{l}\text { Water } \\
\text { temp. }\end{array}$} & Pearson correlation & 1.000 & 0.108 & 0.898 & 0.802 & 0.673 & -0.784 & 0.262 & -0.480 & 0.302 \\
\hline & Sig. (2-tailed) & . & 0.766 & 0.000 & 0.003 & 0.023 & 0.004 & 0.436 & 0.135 & 0.367 \\
\hline & $\mathrm{N}$ & 11 & 10 & 11 & 11 & 11 & 11 & 11 & 11 & 11 \\
\hline \multirow[t]{3}{*}{$\mathrm{pH}$} & Pearson correlation & 0.108 & 1.000 & 0.200 & 0.130 & 0.284 & 0.023 & -0.550 & -0.649 & -0.327 \\
\hline & Sig. (2-tailed) & 0.766 & . & 0.580 & 0.721 & 0.426 & 0.949 & .099 & 0.042 & 0.357 \\
\hline & $\mathrm{N}$ & 10 & 10 & 10 & 10 & 10 & 10 & 10 & 10 & 10 \\
\hline \multirow{3}{*}{$\begin{array}{l}\text { Conduc- } \\
\text { tivity }\end{array}$} & Pearson correlation & 0.898 & .200 & 1.000 & 0.589 & 0.361 & -0.704 & 0.622 & -0.294 & 0.666 \\
\hline & Sig. (2-tailed) & 0.000 & 0.580 & . & 0.056 & 0.276 & 0.016 & 0.041 & 0.381 & 0.025 \\
\hline & $\mathrm{N}$ & 11 & 10 & 11 & 11 & 11 & 11 & 11 & 11 & 11 \\
\hline \multirow[t]{3}{*}{ TDS } & Pearson correlation & 0.802 & 0.130 & 0.589 & 1.000 & 0.652 & -0.683 & -0.212 & -0.619 & -0.161 \\
\hline & Sig. (2-tailed) & 0.003 & 0.721 & 0.056 & . & 0.030 & 0.021 & 0.531 & 0.042 & 0.637 \\
\hline & $\mathrm{N}$ & 11 & 10 & 11 & 11 & 11 & 11 & 11 & 11 & 11 \\
\hline \multirow[t]{3}{*}{ Alkalinity } & Pearson correlation & 0.673 & 0.284 & 0.361 & 0.652 & 1.000 & -0.362 & -0.283 & -0.522 & -0.265 \\
\hline & Sig. (2-tailed) & 0.023 & 0.426 & 0.276 & 0.030 & . & 0.273 & 0.399 & 0.100 & 0.431 \\
\hline & $\mathrm{N}$ & 11 & 10 & 11 & 11 & 11 & 11 & 11 & 11 & 11 \\
\hline \multirow[t]{3}{*}{ DO } & Pearson correlation & -0.784 & 0.023 & -0.704 & -0.683 & -0.362 & 1.000 & -0.186 & 0.467 & -0.192 \\
\hline & Sig. (2-tailed) & 0.004 & 0.949 & 0.016 & 0.021 & 0.273 & . & 0.584 & 0.147 & 0.573 \\
\hline & $\mathrm{N}$ & 11 & 10 & 11 & 11 & 11 & 11 & 11 & 11 & 11 \\
\hline \multirow[t]{3}{*}{ SRP } & Pearson correlation & 0.262 & -0.550 & 0.622 & -0.212 & -0.283 & -0.186 & 1.000 & 0.343 & 0.988 \\
\hline & Sig. (2-tailed) & 0.436 & 0.099 & 0.041 & 0.531 & 0.399 & 0.584 & . & 0.302 & 0.000 \\
\hline & $\mathrm{N}$ & 11 & 10 & 11 & 11 & 11 & 11 & 11 & 11 & 11 \\
\hline \multirow[t]{3}{*}{ SRS } & Pearson correlation & -0.480 & -0.649 & -0.294 & -0.619 & -0.522 & 0.467 & 0.343 & 1.000 & 0.295 \\
\hline & Sig. (2-tailed) & 0.135 & 0.042 & 0.381 & 0.042 & 0.100 & 0.147 & 0.302 & . & 0.379 \\
\hline & $\mathrm{N}$ & 11 & 10 & 11 & 11 & 11 & 11 & 11 & 11 & 11 \\
\hline \multirow[t]{3}{*}{ NO3-N } & Pearson correlation & 0.302 & -0.327 & 0.666 & -0.161 & -0.265 & -0.192 & 0.988 & 0.295 & 1.000 \\
\hline & Sig. (2-tailed) & 0.367 & 0.357 & 0.025 & 0.637 & 0.431 & 0.573 & 0.000 & 0.379 & . \\
\hline & $\mathrm{N}$ & 11 & 10 & 11 & 11 & 11 & 11 & 11 & 11 & 11 \\
\hline \multirow[t]{3}{*}{ Chl-a } & Pearson correlation & 0.728 & 0.322 & 0.473 & 0.953 & 0.720 & -0.662 & -0.347 & -0.789 & -0.298 \\
\hline & Sig. (2-tailed) & 0.011 & 0.364 & 0.141 & 0.000 & 0.012 & 0.027 & 0.296 & 0.004 & 0.374 \\
\hline & $\mathrm{N}$ & 11 & 10 & 11 & 11 & 11 & 11 & 11 & 11 & 11 \\
\hline \multirow{3}{*}{$\begin{array}{l}\text { Phaeo- } \\
\text { pigment }\end{array}$} & Pearson correlation & 0.782 & 0.440 & 0.549 & 0.711 & 0.902 & -0.562 & -0.132 & -0.741 & -0.098 \\
\hline & Sig. (2-tailed) & 0.004 & 0.203 & 0.080 & 0.014 & 0.000 & 0.072 & 0.698 & 0.009 & 0.775 \\
\hline & $\mathrm{N}$ & 11 & 10 & 11 & 11 & 11 & 11 & 11 & 11 & 11 \\
\hline \multirow{3}{*}{$\begin{array}{l}\text { Phyto- } \\
\text { plankton }\end{array}$} & Pearson correlation & 0.714 & 0.480 & 0.489 & 0.773 & 0.836 & -0.572 & -0.217 & -0.799 & -0.185 \\
\hline & Sig. (2-tailed) & 0.014 & 0.160 & 0.127 & 0.005 & 0.001 & 0.066 & 0.522 & 0.003 & 0.586 \\
\hline & $\mathrm{N}$ & 11 & 10 & 11 & 11 & 11 & 11 & 11 & 11 & 11 \\
\hline
\end{tabular}

(7.13 mg/l), conductivity (162.65 $\mu \mathrm{S} / \mathrm{l})$, TDS (77.55 mg/l), SRP (10.52 $\mu \mathrm{g} / \mathrm{l})$, SRS (11.59 $\mathrm{mg} / \mathrm{l}), \mathrm{NO}_{3}-\mathrm{N}(0.14 \mathrm{mg} / \mathrm{l})$. After comparison of the collected data with other man-made 
lakes, it could be said that Safipur lake is not eutrophicated. Its water is not sufficiently enriched with nutrients. $\mathrm{N}$ and $\mathrm{P}$ fertilization has been practiced in the lake one time throughout the year which enhanced plankton for purely a temporary basis. Because of heavy grazing by stocked planktivorous fishes such as silver carp, common carp and tilapia macro-plankton are mostly eliminated and for this reason the lake's phytoplankton population is purely a micro-plankton dominated one. Results of the correlation analysis also support the dependency of phytoplankton biomass on water temperature, $\mathrm{pH}$ and conductivity. Because of high population density $\left(\sim 800 \mathrm{ind} / \mathrm{km}^{2}\right)$ and an extensive agricultural practice the allochthonous nutrient input in most surface water of Bangladesh is a common phenomenon. This process deteriorates water quality very quickly and makes those unsuitable for human use. However, if the water bodies are managed properly and conserved against all sorts of nutrient input of anthropogenic origin, eutrophication could be easily controlled.

Multiple correlation analysis was done among the recorded variables versus (vs) phytoplankyon show significant positive correlation with water temperature, $\mathrm{pH}$, conductivity, TDS, and alkalinity. On the other hand it showed a negative correlation with DO, SRP, SRS and $\mathrm{NO}_{3}-\mathrm{N}$ (Table 5). The levels of significance varied from 1-5\% level in the analysis.

\section{References}

1. Islam AKMN and JK Saha 1975. Limnological study of the Ramna lake at Dhaka. Dhaka Univ. Stud. B. 23: 39-46.

2. Khondker M and L Parveen 1992. Study on the physical and chemical limnology of a shallow, hypertrophic artificial lake. Bangladesh J. Sci. Res.16: 9-16.

3. Khondker M and S Rahim 1991. Investigation on the water quality of Dhanmondi lake I. Physicochemical features. Bangladesh. J. Bot. 20(2): 183-191.

4. Jewson DH, M Khondker, MH Rahman and S Lowry 1993. Auxosporulation of the freshwater diatoms Auslacoseira herzogii in lake Banani, Bangladesh. Diatom Research 8: 403-418.

5. Murphy J and RP Riley 1962. A modified simple solution method for the determination of phosphate in natural wters. Anal. Chim. Acta. 27: 31-36.

6. Wetzel RG and GE Likens 1979. Limnological analysis. W.B. Saunders Co., Philadelphia, pp. 35.

7. Müller R and F Wiedemann 1955. Die Bestimmung des Nitrates in Wasser. In: Jahrbuch für Wasserchem. und Wasserreinigungstech., Verlag Chemie, 12: 247-271.

8. Mackerecth FJH, J Heron and JF Talling 1978. Water analysis: some revised methods for limnologists. Freshwater Biol. Assoc. Publs. No. 36, pp. 120.

9. Kabir MA 1992. Seasonal changes of phytoplankton primary productivity and its controlling components in a mesotrophic pond. M.Sc. thesis, Dept. Bot., Dhaka Univ., pp. 101. 
10. Mukhtar S.SA 1993. Study on the phytoplankton community and its relationships with physical and chemical environment of an artificial lake within Dhaka. M.Sc. thesis, Dept. of Botany, Univ. Dhaka. pp.110.

11. Chowdhury A 1993. Phytoplankton composition, biomass, phosphorus-phytoplankton relationship and general limnology of Gulshan lake. M.Sc. thesis, Dept. Botany, Univ. Dhaka. pp. 69.

12. Rahim S 1991. Investigation on the water quality of Dhanmondi lake by using planktonic and periphytic algae as indicators. M.Sc. thesis, Dept. Botany, Univ. Dhaka. pp. 81.

13. Parveen L 1991. Daily rate of primary productivity and phytoplankton seasonality of Dhanmondi lake in Dhaka. M.Sc. thesis, Dept. of Botany, Univ. Dhaka, pp. 92.

14. Rahman H 1993. Limnology of Banani lake with special reference to Aulacoseira herzogii. M. Sc. thesis, Department of Botany, University of Dhaka.

15. Paul S 2008. Nannoplankton population dynamics and limnological features of some selected pond ecosystems. M. Sc. Thesis, Dept. of Botany, Univ. Dhaka. pp. 94.

16. Singh SR and K Swarup 1980. Studies on the primary production of phytoplankton in Suraha lake (Ballia, India). Int. Rev. Ges. Hydrobiol. 65: 709-717.

17. Klapwijk SP 1988. Biological assessment of the water quality in South Holland (The Netherlands). Int. Rev. d. Ges. Hydrobiol. 73: 481-509.

18. Welch PS 1952. Limnology. McGraw-Hill book Co. New York. pp. 538. 